\title{
Tax Risk Assessment and Management in Private Sector: Evidence from Uzbekistan
}

\author{
Samariddin Elmirzaev \\ Department of Financial Management, Tashkent Financial Institute \\ 60 A, Amir Temur street, 100000, Tashkent, Uzbekistan
}

\begin{abstract}
Risks always obscure the development and stability of enterprises by affecting the profitability and losses in market share, total bankruptcy or closedowns. Absolute impact is often encountered in tax risks which are common factor derived from tax avoidance, tax aggressiveness and mostly unawareness of changes in legislature. This paper studies the tax risk management practices and examines the possibilities of country-specific tax risk management framework for private sector of Uzbekistan based on international best practices and specific features of Uzbek economy.
\end{abstract}

Keywords: Tax risk, tax avoidance, tax aggressiveness, tax risk map, private sector, Uzbekistan

\section{Introduction}

Tax risk management is a worldwide phenomenon with growing prominence in the discourse of both revenue authorities and corporate taxpayers (Mulligan and Oats, 2009). Despite countries' diverse regulatory and business environments, they all come to the understanding that an effective tax risk management system is vital for both parties. Especially in context of transition to market relations and expansion of private sector, tax risk management gains the central position due to double-edged case of growing public need for strengthening fiscal power and providing tax privileges for new and prospective businesses. Being a progressively developing economy, Uzbekistan has been opening new opportunities for business sector with main focus on SME's and new business areas which are "fragile" to any pressures and need government's support for efficient functioning. Tax burdens, lack of capability to market access, competitive environment make them more vulnerable to failures. In condition of healthy and highly competitive business environment, tax burden becomes the key problem and a common factor for bankruptcy in a short period. Even tax burden is in optimal setting, sometimes inappropriate response to tax risks and early warning signals of existing risks cause to fail. The need for tax risk management mainly roots from these two common factors and in part from the existence of ongoing tax legislations. However, tax risk identification and evaluation are the central links of the tax risk management, whose accuracy is directly related to the success or failure (Cai et al, 2015). Therefore, promoting tax compliance as the goal, the risk management as the guidance, taking the information tube tax and the hierarchical classification as the basis, set up tax services, risk monitoring, risk response to the new tax management system, this tax sources of specialized management model has become the direction of the reform of tax system, tax risk management as a new concept received extensive attention of tax authorities. And international experience proves that understanding the tax risk management does not suffice to operate in the industry; tax risk identification, assessment, prevention and control are needed. But effective tax risk management should evaluate the environment, opportunities and weaknesses in condition of changing legislative conditions e.g. tax exemptions, preferential taxation, custom fee bonuses, and economic conditions e.g. trade facilitation, export support policy, solvency facility.

\section{Literature Review}

During the last few years, governments have been continuously encouraging good corporate governance and developing guidance for sound tax risk management (KPMG, 2012). Tax risk management is timely because firms' sensitivity to tax risk has increased substantially as taxing authorities around the globe seek to raise revenue more efficiently by identifying and auditing firms that exhibit greater tax risk (Ernst \& Young 2012). The concept of tax risk is new to the literature, and thus, there is considerable disagreement over what conceptually and empirically constitutes tax risk (Neuman, Omer, and Schmidt, 2014). Optimal tax risk management attracted the focus of researchers and policymakers in early 1980s because of its wide coverage of damage. Most researchers studies mainly two origins of tax risk: economic and legal. They investigated the issues of tax aggressiveness, tax avoidance, tax shelters and tax uncertainties. Guenther, Matsunaga, and Williams in 2013, and Saavedra in 2014 studies the economic outcomes of tax risks, while Rego and Wilson in 2013 and Dyreng, Hanlon, and Maydew in 2014 found the roots of tax risks from legislative changes. As Wilson proved in 2009 that tax risk is an important type of risk that can generate significant costs not only in terms of monetary penalties but also reputational damage. The existence of an appropriate tax risk management framework is vital to the financial and reputation and business well being any business organisations, especially those with public accountability. 


\subsection{Importance of tax risk management for private sector of Uzbekistan}

As a rapidly growing transition economy, Uzbekistan's economic system faces regular changes and systemspecific conditions. These modifications and their consequent circumstances pose risks for enterprises, including internal and external tax risk which is a widespread factor of chain of problems between enterprises and tax authorities.

Private sector in Uzbekistan is comparatively new in terms of establishment. Emerging business psychology and business conduct skills often obscure the need for taking rapid action to legislations in economic and corporate sector. Foundation of private and public sector dates back to dissolution of former Soviet Union and establishment of independent Uzbekistan. Since the early years of national independence Uzbek government has been supporting private sector and has been eliminating the outdated principles of communistic view and residues of planned economic system in new market oriented national economy. Introduction of private ownership rights, corporate structure and free economic activity formed a favorable business environment and a progressive private sector. And nowadays private sector generates the biggest share of gross production in the economy. Therefore, stability and profitability of private sector enterprises hold an important position in economic development of the country. In order to ensure profitability, stability and access for private sector enterprises, they should evaluate the impact and implications of potential risks and existing uncertainties in the market and the whole economic system. As outlined, prudent and efficient tax risk management should be structured around several elements which are needed for choosing appropriate approach and taking measures. Primary stage of tax risk managements is to identify the potential types of tax risk and investigate their origin and impact areas. Literatures present different views on how to identify and classify tax risks, but from preliminary case-based analysis shown that optimal model of risk identification for private sector of Uzbekistan is micro- factors approach of general tax identification method. Identification produces a comprehensive list of potential tax risks and sometimes opportunities. At this stage, enterprise's organizational and business profile should be considered in order identify industry-led tax risks because of multiple and preferential taxation principle of Uzbekistan.

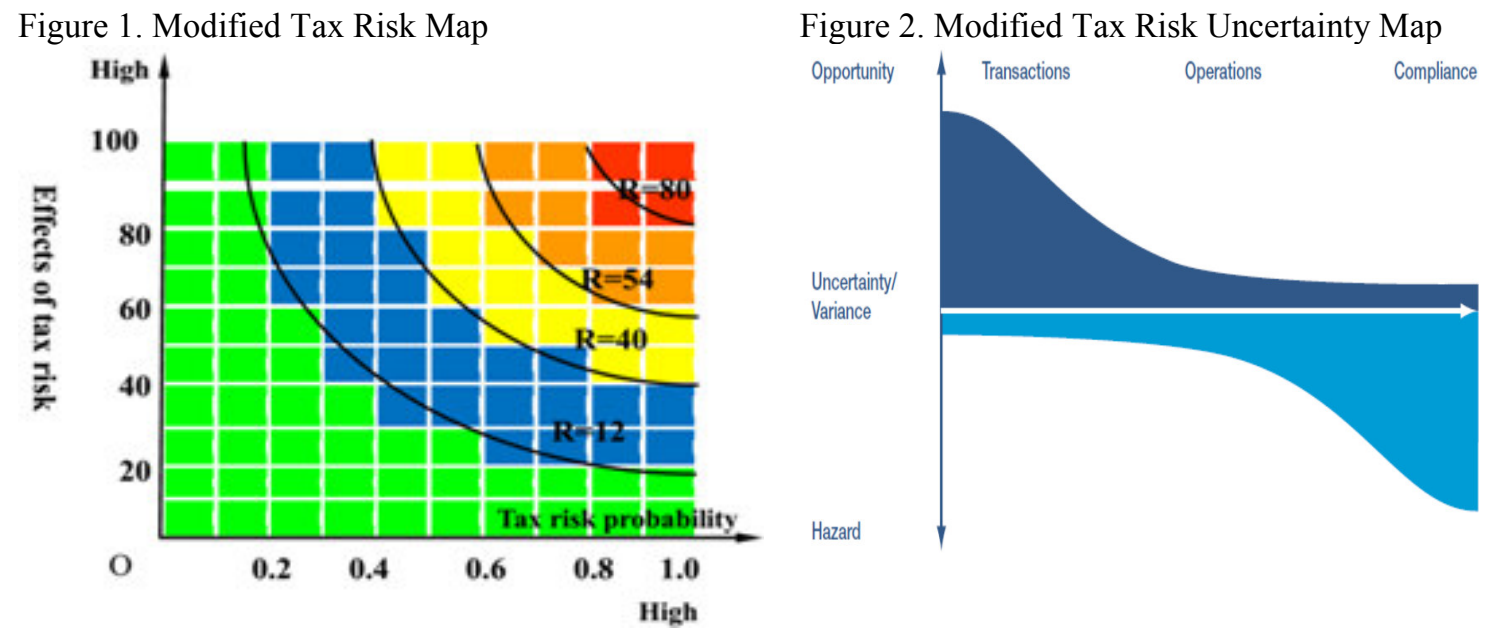

Source: Authors' modifications from Cia, 2009 and PWC, 2014

In international practice, companies create a risk map for the particular condition of the market, industry, economy or legal structure. They propose a set of solutions and simulation model in case of aggressive risk with high hazard to company. Tax risk mitigation measures also follow this procedure. Based on international experience and distinctive feature of Uzbek private sector, tax risk and uncertainty map in Figure 1 and 2 can be used as early warning signals.

\subsection{Specific Tax Risk Management Framework for Enterprises in Uzbekistan}

Developing corporate governance and managerial practices has changed the landscape of tax risk management in Uzbek private sector as a vital area which requires a robust strategy. Several approaches to tax risk mitigation and tax avoidance have been proposed. However functional sector-related issues made these approaches to be rethought and to be reviewed. Based on the international best practices and globally recognized principles of tax risk management, the authors developed a framework for private sector enterprises of Uzbekistan (Figure 3). 
Figure 3. Tax risk management stages of special framework for private sector enterprises of Uzbekistan

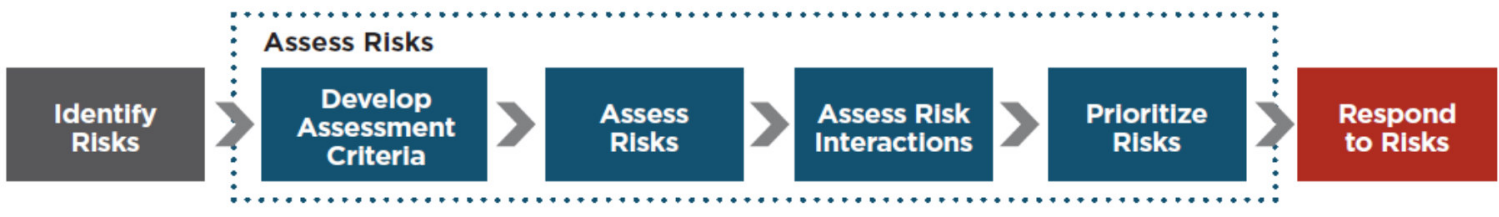

Source: Authors' development from KPMG Report, 2015

Tax risk identification. This stage represents the awareness of the enterprise to different types of tax risks. Tax risks are in different in terms of origin and impact areas such as from change in business structure, amendments in related laws etc. Enterprises should indentify the type and character of the emerging tax risk at first, as classified in Figure 4.

Figure 4. Tax risk categories by origin and impact

Transactional risk Specific

Operational risk

Compliance risk

Financial accounting risk

Source: Author's compilation

Generic
Portfolio risk
Ranagement risk, and
Reputational risk

Portfolio risk

Reputational ris

Tax Risk Assessment. This stage includes four important sub-stages: development of risk assessment criteria, assessment of risk, assessment of risk interactions and prioritization of risk; and evaluates opportunities of how those risks are managed and mitigated consistent with the overall objectives of the enterprises on tax risk. Development of set of tax risk assessment parameters, in line with impact of tax risks, risk vulnerability and speed should be assessed (Author recommends risk assessment criteria proposed by international auditing and business consulting companies provided in Figure 5). In some cases, interaction among risks should be investigated because in transition economies tax risks may generate another type of tax risk.

Figure 5. Tax risk impact assessment scale

\begin{tabular}{|lcr|} 
Low & Medlum & Hlgh \\
\hline 0 & 5 & 10 \\
\hline Conservatlve & & Aggresslve \\
Low appetite for risk & & Rlsk taker
\end{tabular}

Source: PWC, 2014

Tax risks can be assessed by responding following requirements:

1. Do consequences of external factors such as economic, environmental, political, technological and social factors have an impact?

2. What policies and procedures are used to ensure tax risks and exposures?

3. Are possible impact areas identified and losses are estimated?

4. Does risk assessment technique include retrospective and prospective analysis?

5. Are such secondary risks included along with primary risks in the risk assessment?

6. Do residual risks exist?

Response to Tax Risk. This stage is a set of several measures for mitigating risks for short and long term depending of enterprise's tax risk management strategy. Most experts recommend to control and monitor against all types of tax risks through different tools and analyses. Control measures include diverse actions e.g. approvals, authorisations, reconciliations, and reviews as well as policies on areas such as segregation of duties. Tax risk controls should be base on following actions:

- $\quad$ preventative and detective control activities

- review at appropriate levels

- control over tax planning, transactional issues and tax change

- timely identification of changes in tax laws, regulations and decisions

- accurate application of the tax laws to the data

- timely and accurate reporting and payment of taxes

Risk monitoring coordinates the efficiency of control measures and their compliance with designed tax risk 
management policies, laws and forecast. Monitoring should be strictly conducted based on accomplishment of following tasks:

- $\quad$ ongoing basis monitoring over tax risk assessment

- monitoring over effectiveness of the risk assessment

- monitoring over design of controls to mitigate identified risks

- monitoring over internal control procedures

- monitoring over effective coordination of control environment and risk assessment

\section{Conclusion and Recommendations}

Private sector of Uzbekistan is in a favourable condition with healthy competition and governmental support for new and restructured enterprises. Access to market and gaining a share in output of particular industry is comparatively easy thanks to well-functioning laws on business protection and support. However, as a response to government's action to create a sound business climate, as in all economies, it imposes several taxes and changes the installed rates. Tax risks root from them in most cases indifferent level and impact areas. These issues are sufficiently discussed and provided with possible theoretical and empirical solutions and recommendations as follows:

1. Increasing the understanding of tax risk management strategies and tax position of enterprises;

2. Increasing the awareness of enterprises on core principles, amendments and relevant parts of Tax Code of Uzbekistan;

3. Increasing a trusting and transparent relationship with tax authorities at firm-level and industry-level;

4. Maintaining a sound and effective tax risk management actions and ensuring relevant documents to the tax authorities requested;

5. Monitoring the tax compliance of the senior and tax administration staff of the enterprise;

6. Issuing the tax risk manuals and conducting training course for accounting and tax administration staff on tax compliance and risk avoidance;

7. Introducing the tax risk map and uncertainty map to enterprises risk managements strategies as shown in Figure 1 and 2.

8. Ensuring the appropriate and correct use of tax risk management framework tailored to Uzbek private sector as shown in Figure 3.

9. In order to ensure the appropriate and efficient use of tax risk management framework, and reach the optimal tax risk level, enterprises should follow three-pillar cycle of principal actions: (a) implementation of control over tax risk management policy of an enterprise, (b) review the effectiveness of control and monitoring, (c) determination of optimal tax risk.

\section{References}

1. Cai, D., Ni1, N. and Cai, J. (2015). Big Enterprise Tax Risk Management: Warning, Simulation and Application. International Journal of u- and e- Service, Science and Technology . Vol.8, No.4 (2015), pp.135146.

2. Freedman, J. (2015) Managing tax complexity: the institutional framework for tax policy making and oversight. University of Oxford Centre for Business Taxation. WP 15/08.

3. James, S. Svetalekth, T. and Wright, B. (2011).The Benefits of a More Strategic Approach to Tax Administration and the Role of Performance Indicators. Discussion Papers in Management. 07/11

4. - (2014).Risk transformation and tax Deloitte Touche Tohmatsu Limited. p 8-9. 